\title{
A revision of the South American snake genus Thamnodynastes Wagler, 1830 (Serpentes, Colubridae, Tachymenini). I. Two new species of Thamnodynastes from Central Brazil and adjacent areas, with a redefinition of and neotype designation for Thamnodynastes pallidus (Linnaeus, 1758)
}

\footnotetext{
Joseph R. Bailey ${ }^{1}$, Robert A. Thomas ${ }^{2}$ and Nelson Jorge da Silva Jr. ${ }^{3}$

1 Department of Zoology, Duke University. Durham, NC 27706 USA (deceased).

2 Center for Environmental Communications, Departments of Communications and Biological Sciences, Loyola University. P. O. Box 199, 6363 St. Charles Avenue, New Orleans, LA 70118-6195, USA. E-mail: rathomas@loyno.edu.

3 Centro de Estudos e Pesquisas Biológicas, Universidade Católica de Goiás. Av. Universitária, 1440, Setor Universitário, 74605-010, Goiânia, GO, Brazil. E-mail: herp@terra.com.br.
}

\begin{abstract}
A revision of the South American snake genus Thamnodynastes Wagler, 1830 (Serpentes, Colubridae, Tachymenini). I. Two new species of Thamnodynastes from Central Brazil and adjacent areas, with a redescription of and neotype designation for Thamndynastes pallidus (Linnaeus, 1758). Two new species of Thamnodynastes whose ranges are entirely or largely in Brazil are described. Thamnodynastes pallidus, one of the most easily identified species of the genus, is redefined and a neotype is designated, and Coluber strigilis Thunberg is placed in its synonymy, thus clarifying an enduring state of confusion in the taxonomy of this genus.

Keywords: Serpentes, Colubridae, Xenodontinae, Tachymenini, Thamnodynastes sertanejo sp. nov., Thamnodynastes lanei sp. nov., Thamnodynastes pallidus, Thamnodynastes strigilis.
\end{abstract}

\section{Introduction}

Until recently, herpetological reports from northern South America that include specimens of Thamnodynastes Wagler, 1830, mention two species. One species that is easily identified by

Received 9 October 2004.

Accepted 21 June 2005.

Distributed December 2005. dorsal scale row counts and ventral pattern is $T$. pallidus (Linnaeus, 1758). The other, normally with keeled scales and often with great variability, depending on the source of specimens, is traditionally called T. strigilis (Thunberg, 1787).

A study of the widespread T. pallidus, and examination of the syntypes of Coluber strigilis (Figures 1 and 2), reveal the presence of a number of yet undescribed species. We herein redefine Thamnodynastes pallidus, allocate 
Coluber strigilis to its synonymy, designate a neotype, and describe two new species.

\section{Materials and Methods}

All scale counts, notations, and terminology used follow the norm for the field (we note numbers of supralabials and which of those are in contact with the eye; numbers of loreals, pre and postoculars, and temporals [members of this genus most often have primary temporals that touch the rear of the postoculars and secondary temporals that touch the rear of the primaries, and there are often tertiary temporals that touch the secondaries]; and infralabials and how many touch the primary and secondary genials). Beyond these scale features, Thamnodynastes species have the "normal colubrid complement of head scales" (one rostral, two internasals, two prefrontals, one frontal, two parietals, two supraoculars, two pairs of nasals, one mental, and two pairs of genials). Any anomalies are mentioned. Ventral scale counts were taken as suggested by Dowling (1951a), subcaudal counts include the count down the left row of double scales and include the terminal spine. Scale row reductions follow Dowling (1951b), with the modifications and summarization model of Thomas (1976).

Measurements of the body were taken in a straight-line with a meter stick: total length is from the tip of the snout to the tip of the tail and tail length was taken from the rear of the cloacal scale to the tip of the terminal spine (for both measurements and counts, specimens lacking an obvious terminal spine were considered to have incomplete tails). Head measurements were taken with calipers to the nearest millimeter. Head length was measured from the tip of the rostral to the rear margin of the right dentary; head width was taken at the widest point, and eye length was taken in a straight line from the anterior margin of the eye to the rear margin.

Mention of the projections of the eye are a description of where on the lateral surface of the head (using named scales as a reference) the measured length of the eye falls when projected forward from the front margin of the eye.

To place size in context, we report the total length size range for the top $25 \%$ of specimens. Total length is abbreviated TL, snout-vent length is SVL, head length is HL, head width is HW, and subcaudals is SC.

All tooth counts are of single series and all except the maxillary (most of which were done by cleaning in situ bones) are from prepared skulls. With the maxillaries, particular care was taken to count the smallest anterior tooth (or its socket), which is easily overlooked, thus rendering incorrect counts. When referring to maxillary teeth, “ $12+2 \mathrm{G}$ ” means 12 prediastemal teeth followed by 2 grooved postdiastemal fangs.

The conclusions of this study are based on the examination of specimens borrowed from collections cited in the acknowledgment section (Appendix I).

\section{The Thamnodynastes pallidus Group}

The pallidus group consists of four species, the wide-ranging $T$. pallidus, $T$. longicaudus Franco et al. (2003) of northeastern Brazil, and two new species (one described in this paper, $T$. sertanejo, and another in a forthcoming paper) with restricted distributions in widely scattered regions. Nowhere are any of them abundant and T. pallidus is sympatric only with the species that will be described in another paper (from the Upper Amazon and its tributaries).

The pallidus group appears to be the most specialized in the genus, being very slender, having the fewest dorsal scale rows within the genus, possessing a hood that is spread defensively, and having a blotched dorsal and ventral pattern (T. pallidus is an exception to the patterns having ventral stripes and black stripes on a tan dorsum). They are characterized as a group by slender body and long tail; short head with large eyes and obviously elliptical pupil; belly patterns are either the most intricately striped (T. pallidus and one other new species 
from the llanos of Venezuela and Colombia) or uniquely blotched (one, T. sertanejo, is described in this paper and another mentioned above from the Upper Amazon); dorsal scales smooth, elongate and without pits; dorsal reductions involve the paravertebral rows once and lateral rows one or more times; the hemipenis is short, simple or shallowly bifurcate, beset with small slender spines not longer than the height of the sulcal lips, terminal calyces poorly developed or absent, the sulcus bifurcates distally or simply opens onto a terminal clear space.

Three of the four species are known to flatten the neck to show their striking pattern of light and dark cross bands; the fourth member (T. pallidus) is unique in having the skin of the neck between the scale rows bright lemonyellow in life.

Scale Row Reduction in the pallidus Group Data on scale row reduction are available for 69 specimens in the pallidus group. One of the diagnostic features of the pallidus group is the almost invariable (93\%) occurrence of one dorsal reduction involving the fusion of the paravertebral scale row with its lateral neighbor. In no specimens did more than one paravertebral reduction take place, only once did the paravertebral reduction involve the change from 19 to 17 rows (in the only female examined of the species having 19 scale rows at mid-body), and in no instance was the paravertebral row involved in a reduction from 13 to 11 rows. In the rest of the genus, a paravertebral reduction occurs only as a rare anomaly, and then associated with other anomalous aspects of row reduction.

The points of reduction from 17 to 15 and 15 to 13 are often very close, in a few instances identical in $T$. pallidus, and the paravertebral reduction may either precede or follow a lateral reduction. There is no obvious sexual dimorphism in the row dropped, but females tend to have one less reduction than do males (common among colubrids, and assumed to be an accommodation for pregnancy). The position of the reductions is virtually identical in the sexes.
Thamnodynastes pallidus (Linnaeus, 1758)

(Figure 3)

Coluber pallidus Linnaeus, 1758: 221. Type in the Royal Museum, Stockholm, misslabelled as Coluber mycterizans (Andersson, 1899: 17). Type locality: “Habitat in Indiis.”, in error. Lönnberg (1896: 26) noted that the types were lost.

Coluber strigilis Thunberg, 1787: 22. Syntypes: ZMUU (Linnaean Collection) 154, subadult female; ZMUU (Linnaean Collection) 292, an adult male (both without locality). Discussed by Lönnberg (1896: 38).

Natrix punctatissimus Wagler, 1824: 39, Pl. 14. Lectotype: ZSMH 2043/0, a male collected by J. B. von Spix in Bahia, Brazil; other two syntypes lost (Hoogmoed and Gruber, 1983: 332-333).

Thamnodynastes punctatissimus (Wagler): Wagler, 1830: 182.

Dipsas punctatissima (Wagler): Schlegel, 1837: 292.

Sibon punctatissimus (Wagler): Berthold, 1840: 900.

Thamnodynastes pallidus (Linnaeus): Andersson, 1899: 17.

Dryophylax pallidus pallidus (Linnaeus): Amaral, 1930a: 103; 1930b: 210.

Nomenclatural Remarks - The original description, due perhaps to its brevity and an erroneous locality ("Indiis"), was overlooked or ignored by herpetologists until its resurrection by Andersson (1899). The original description in the 10th edition of Systema Naturae (Linnaeus 1758) was repeated verbatim in the 12 th edition (Linnaeus 1766). In the 13th edition (a completely new work, not actually a new edition, fide Vanzolini 1977), Gmelin (1789) added the following: ventral and subcaudal counts of two further specimens, its occurrence in South America (as well as India, which is incorrect), and the description ends with "Longitudo ad 1 1/ 2 pedem”. Andersson (1899) discovered the type specimen and revalidated the name $T$. 

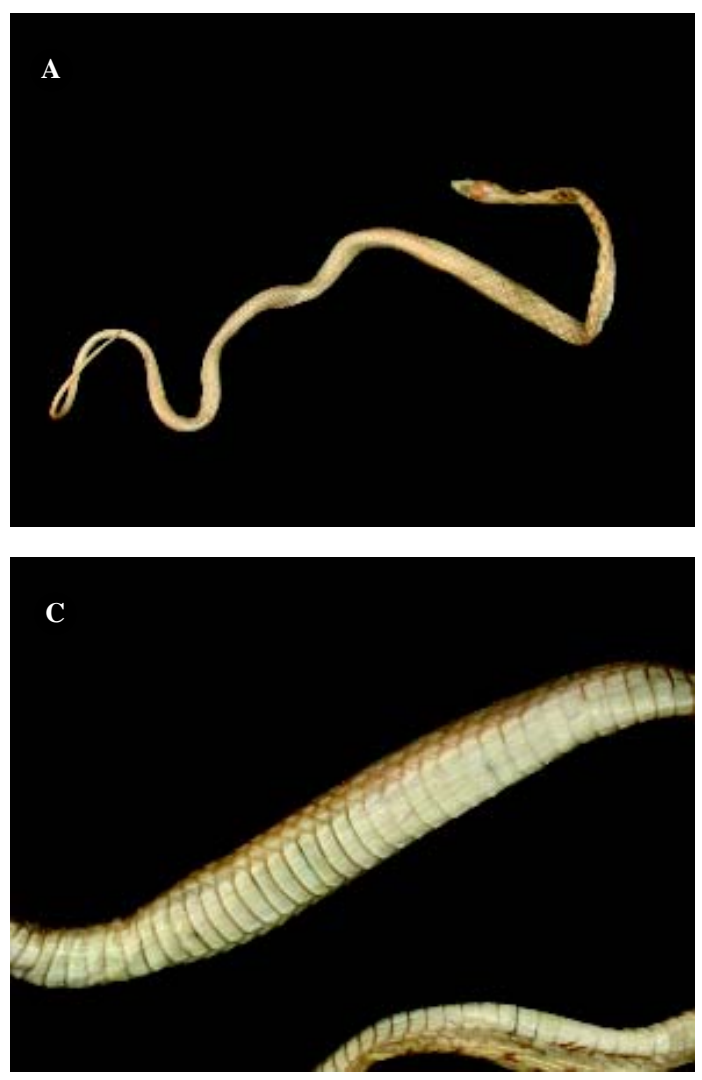

Figure 1 - Syntype of Coluber strigilis Thunberg, 1787 (ZMUU 154). (A) dorsal view, (B) ventral view, (C) close-up of venter. Photos by Klas Allander.

pallidus to replace $T$. punctatissimus. These types are now lost.Thunberg (1787), in another inadequate description with no locality, described Coluber strigilis, which in turn was ignored until Lönnberg (1896) misalligned the type with Coluber nattereri Mikan, which, by that time had become a catch-all name for the genus. Lönnberg failed to redescribe the type specimen so his action only obfuscated the situation further. Fortunately, we have been able to study the type material for Coluber strigilis, of which there are two specimens, and both are unquestionably $T$. pallidus of this paper. Pertinent data include (ZMUU 154, followed

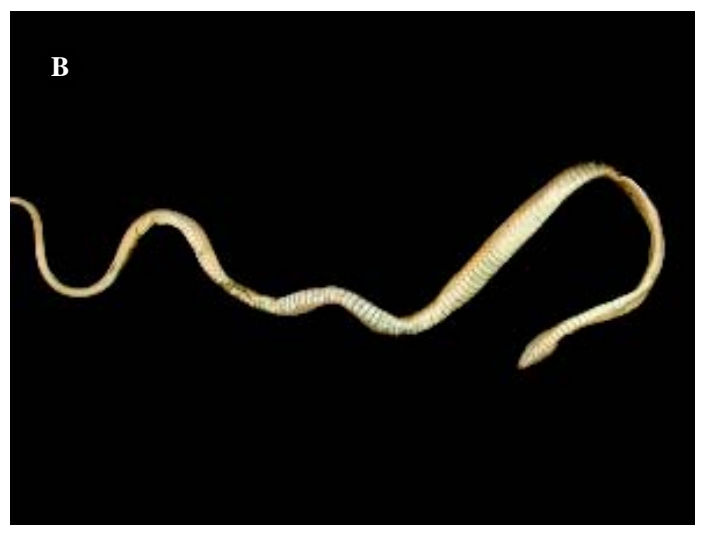

parenthetically by ZMUU 292): sex female (male), dorsal scales 17-17-13 (17-17-13), ventrals 142 (152), cloacal single (single), subcaudals incomplete (92), maxillary teeth 19+2G (16+2G), SVL 234 mm (363), tail length incomplete $(146 \mathrm{~mm})$. The ventral striping of both is typical of the species and both have a paravertebral dorsal reduction.

We designate ZMUU 292 as the lectotype for T. strigilis (Thunberg 1787) (thus, ZMUU 154 is the paralectotype). We choose to designate the lectotype in order to designate it as the name bearer of the species in order to facilitate its use below as the neotype for $T$. pallidus.

The fact that $T$. strigilis is a junior synonym of T. pallidus was first published by Cei (1993: 692), in which he noted RAT as his source for the information.

Neotype Designation - In the absence of the original type series, reported lost by Lönnberg (1896), we believe that nomenclatural stability will be enhanced in this complicated array of species by designating a neotype for $T$. pallidus (Linnaeus, 1758) It is reasonable to choose the lectotype of its new junior synonym, Coluber strigilis Thunberg, 1787 (permissible according to Article 72.6 of the International Code of Zoological Nomenclature). 


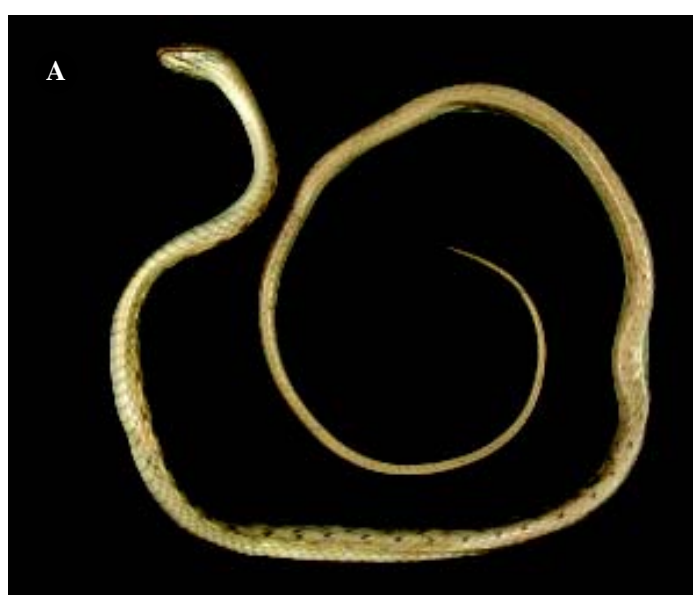

We designate ZMUU 292 (Figure 2), an adult male, as the neotype for Thamnodynastes pallidus (Linnaeus, 1758). Specimen $509 \mathrm{~mm}$ TL, tail $146 \mathrm{~mm}$ (it has been slit open for sex determination); tail/TL 28.7\%; dorsal scales 1717-13; dorsal scale row reduction:

$$
17(10) \frac{3+4(105)}{3+4(110)} 14 \frac{7+8(115)}{7+8} 13(152)
$$
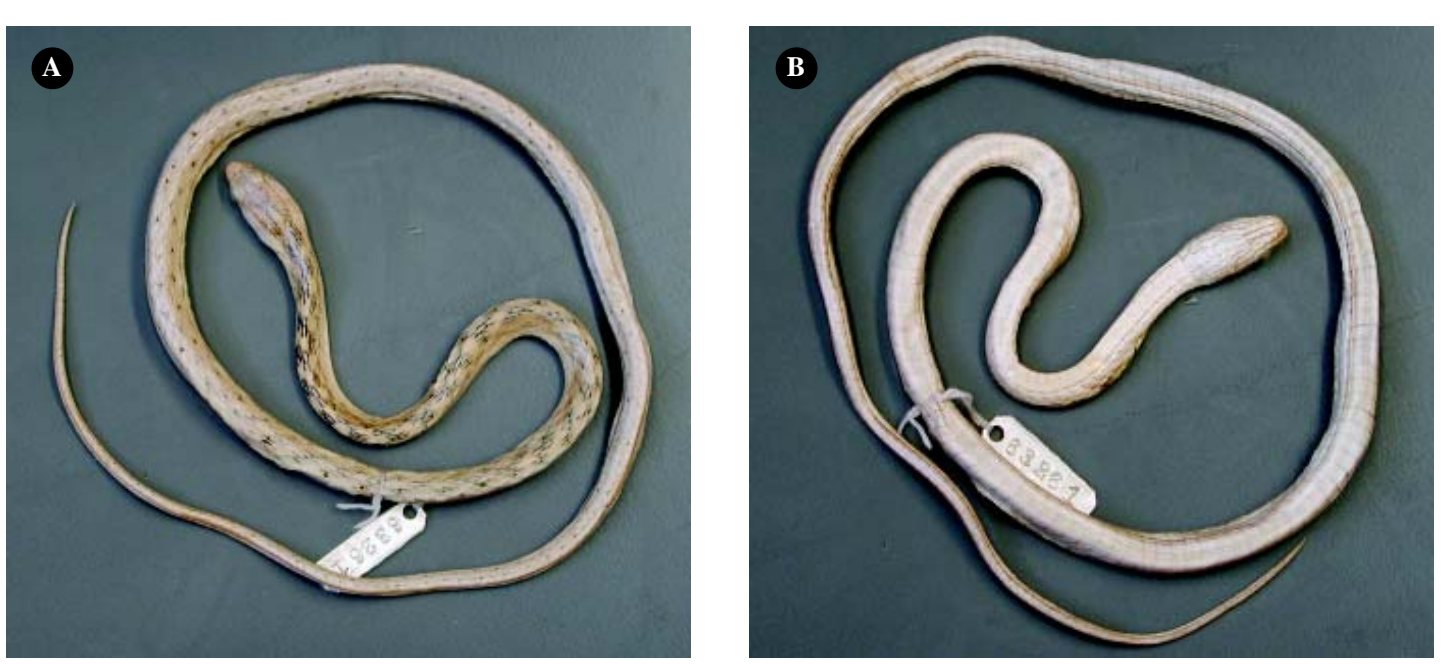

Figure 3 - Thamnodynastes pallidus (UMMZ 6321). (A) dorsal view, (B) ventral view.
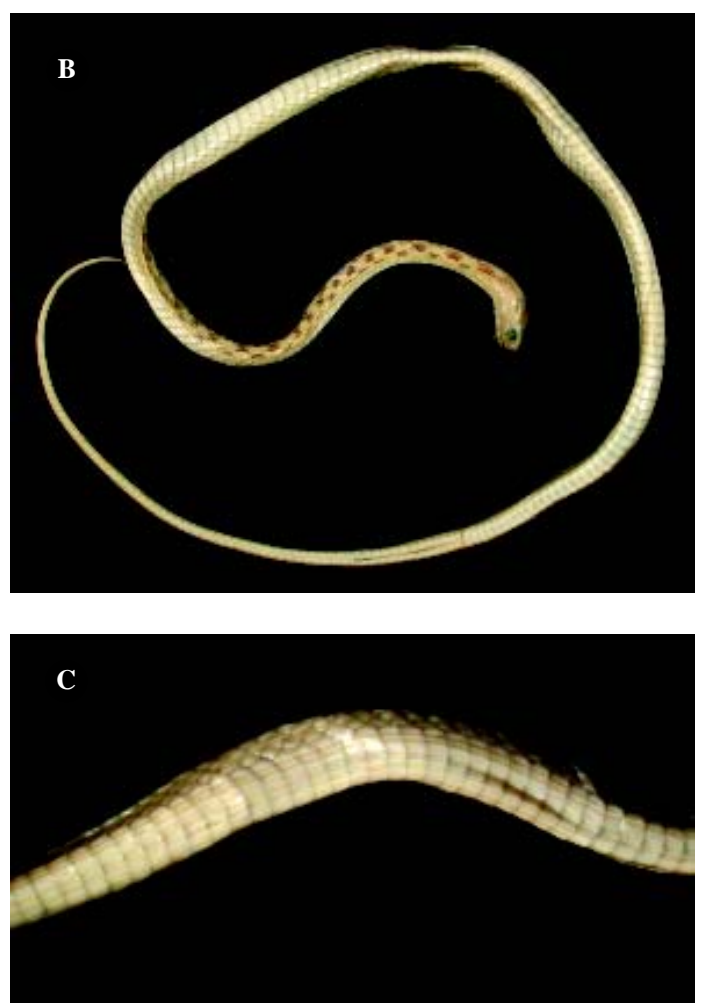

Figure 2 - Syntype of Coluber strigilis Thunberg, 1787 (ZMUU 292). (A) dorsal view, (B) ventral view, (C) close-up of venter. Photos by Klas Allander.

Phyllomedusa - 4(2), December 2005 
Ventrals 152; cloacal scale single; subcaudals 92; supralabials $8 / 8,4+5$ in contact with eye; infralabials $9 / 9,5 / 5$ in contact with genials; preoculars $1 / 1$; postoculars $2 / 2$; temporals $2+3$ / $2+3$; loreals $1 / 1$; hemipenial length $7 \mathrm{SC}$; maxillary teeth $16+2 \mathrm{G}$.

The specimen is rather pale due to bleaching, but the dorsum is obviously tan with pigmented chevron patterns down the first two-thirds of its length, and the venter is cream with obvious narrowly parallel stripes on each side of the venter and four down the middle (each is a stripe with a hollow center) (Figure 2C). The chin has a moderate amount of palely pigmented streaks.

Diagnosis - Thamnodynastes pallidus has smooth dorsal scales, usually $17-17-13$ or -11 (rarely 19 at midbody); cloacal scale usually single; maxillary teeth $16-20+2 \mathrm{G}$; eye very large; ventrals, males 149-163, females 136149; subcaudals, males 85-100, females 78-97; hemipenis about 6-8 SC long, moderately stout, finely spinous, unforked and with sulcus simple; posterior ventral pattern of three sets of quadruple lines (or approximated pairs).

The following characters may be used to separate $T$. pallidus from sympatric congeners that have been described (characters are given for the sympatric species, followed parenthetically by characters of T. pallidus): T lanei (see description below) has keeled (vs. smooth) dorsal scales, dorsal scales 17-17-15 (vs. 17-1713 or less), and a divided (vs. single) cloacal scale; T. chaquensis with slightly keeled scales (vs. smooth), dorsal scales 19-19-15 (vs. 17-1713 or less), divided (vs. single) cloacal scale, and venter heavily suffused with dark pigment (vs. pale); T. attenuata has dorsal scale rows 1919-15 (vs. 17-17-13 or less) and a divided (vs. single) cloacal scale.

Variation - Adult size range (based on our largest $25 \%$ of specimens) is $598-635 \mathrm{~mm}$ TL in males, and 570-642 $\mathrm{mm}$ in females; tail/TL $26.9-30.0 \%(\bar{x}=28.8 \pm 0.9, n=21)$ in males, 26.1$30.5 \%(\bar{x}=28.4 \pm 1.0, n=40)$ in females; dorsal scale row formulae 17-17-11(3) or 17-1713(61), scales smooth, without pits, with following complete scale row reduction summary for five specimens:

$$
\begin{array}{cl}
{[1] 4+5 \bar{x}=100.2} & {[1] 7+8 \bar{x}=105.0} \\
17(10) & \frac{[4] 3+4(92-105)}{[4] 6+7(99-112)} \bar{x}=149.0 \\
{[4] 3+4(94-104)} & {[3] 6+7(97-111)} \\
{[1] 7+8 \bar{x}=100.8} & {[1] 7+8 \bar{x}=106.2} \\
& {[1] 3+4}
\end{array}
$$

Ventrals $149-163(\bar{x}=154.5 \pm 3.9, n=22)$ in males, 136-149 ( $\bar{x}=144.0 \pm 3.4, n=40)$ in females; cloacal scale single (63), infrequently divided (9); subcaudals 85-100 ( $\bar{x}=90.4 \pm 4.6$, $\mathrm{n}=22)$ in males, $78-97(\overline{\mathrm{x}}=84.2 \pm 4.0, \mathrm{n}=40)$ in females; ventrals+subcaudals $230-260(\overline{\mathrm{x}}=$ 245.1 $\pm 7.1, \mathrm{n}=21$ ) in males, 215-243 $(\bar{x}=228.1 \pm 5.9, n=40)$ in females; supralabials $7(1), 8(101)$ or $9(2)$, supralabials entering orbit $4(1), 3+4(1)$, or $4+5(104)$; infralabials $8(5)$, $9(98)$, or $10(2)$, with $4(2), 5(60)$, or $6(1)$ touching the genials; loreals $1(94)$; preoculars 1(84) or 2(4); postoculars 2(81) or 3(7); prediastemal maxillary teeth 16(3), 17(5), $18(12)$, 19(11), or 20(4), followed by two postdiastemal enlarged grooved fangs.

Slender, with long tail, eye very large, its diameter more than twice its distance from the lip and, projected forward, it nearly reaches the rostral; diameter of eye in head length 19.7$24.2 \%(\bar{x}=21.3, n=7)$. The umbilicus in term embryos centers on ventral 131 or 132 (4 males) and 122 and 126 (2 females); term embryos measure SVL 115-120mm (4 males), 108$110 \mathrm{~mm}$ (2 females).

Color and Pattern - Based on AMNH 2665, 8665, 36134, 46472, 73841, and 101960: chin and throat unmarked except for a few tiny dark dots (Figure 4); on anterior ventrals a fine streak on either side becomes a double (hollow) streak at about heart level; before midbody this has become a pair of double streaks which continue about to the cloaca where it becomes once more a double streak on each side of the tail venter (Figure 5); in AMNH 36134 the double streak never becomes paired doubles; a variable amount of accessory pigment develops including 
another pair of double streaks medially in the most extreme specimens (AMNH 73841, 8665); some general sprinkling of fine dots is sparse in AMNH 36134 to rather profuse in AMNH 101960; head pale, tan to brown on top, lighter elsewhere or with scattered dark dots; a double (dark-edged, pale-centered) dark streak extending from margins of the postoculars at rear center of eye through corner of mouth (Figure 6) disappearing on side of neck; this postocular bar slender, about $2 \times$ diameter of nostril; in most specimens showing most contrast (AMNH 101960) there is a similar anterior bar from center of orbit to top of nasal; also in specimens showing contrast, a single or double streak from top of eye across outer edge of parietals outlines the darker crown and joins a dark paravertebral line bordering a light nuchal stripe on the nape; this stripe is interrupted after about 10 scales by a series of medial I-shaped dark marks every 3-4 scales, alternating with similar paravertebral series centering on the 6th rows then another series on the 4th rows making 5 series in all; in fresher specimens, the light scales of the dorsalmost rows have yellow skin between them; the five series of dark dorsal-spots are lost at about midbody and the lateral-most row becomes transformed, along with a double stripe on rows $1-2$, into a series of lateral streaks resembling the ventral ones; the paravertebral spots become reduced to dark dots on every two or three scales of the 6th rows; the vertebral series is completely lost.

Hemipenis - Based on dissections of AMNH 73841, MNRJ 2625, IBSP 1847, MZUSP 3499 and SCN 726: organ 6.5-7.5 SC long, simple or very faintly bilobate; sulcus simple, opening on a clear triangular space at tip; small spines beginning on absulcate side and attaining about 12 transverse rows opposite SC 4 where they are longest, thence they decrease gradually to become papillae or spinulate calyces distally; there are no enlarged basal hooks and the lips of the sulcus may be beset with tiny spinules; in stoutness, the organ is intermediate between the very slender $T$. lanei and its near relatives and the stout hemipenes of the $T$. nattereri and $T$. strigatus groups.

Distribution - The range of T. pallidus seems to be the Amazon and upper Orinoco watersheds from central Bolivia to eastern Colombia and southern Venezuela and the Guianas, and to eastern Pará, Brazil (Figure 7). This is a lowland species. From Buena Vista, Bolivia, specimens are from of $450 \mathrm{~m}$ and $400 \mathrm{~m}$, which are the maximum recorded elevations. On the Río Ucayali in Perú and the Río Hacha in Venezuela, the highest stations approach the $200 \mathrm{~m}$ contour. All other records are lower. Duméril et al. (1854), Jan (1863), and Jan and Sordelli (1872, Pl. 2, Figure 2), reported T. pallidus from Cayenne, French Guiana (we have a specimen from 11.5 km E Sinnmary, km marker 91 TCWC 65403).

We originally thought that this species has a discontinuous distribution, also occurring in the forested east coast of Brazil, Bahia to Pernambuco. It appears that those specimens represent Thamnodynastes almae Franco and Ferreira, 2002.

Natural History and Ecology - Habitat data are few; a specimen from São João on the Rio Solimões bears a note "on ground on bank of river.” Cunha and Nascimento (1978) state that (in translation) "It lives by preference on damp ground in forests or on forest borders with old secondary vegetation. Habits nocturnal...... It feeds on frogs and insect larvae (coleopteran and perhaps others), in accord with examination of stomach contents.” We have an additional five anuran food records of which at least three are hylids.

William W. Lamar (pers. comm.) reports the following about observations of $T$. pallidus in the Iquitos, Perú, region: "I find this species predictably in frog choruses, just like Leptodeira. They are avid frog predators. The easiest place to locate this species is by night on floating islands of vegetation (Pistia and Hyacinths) where they crawl about in quest of frogs. Choruses on these islands are predominantly Hyla punctata, H. granosa, H. triangulum, Sphaenorhynchus carneus, S. dorisae, and S. lacteus." He also said, "I collected a 


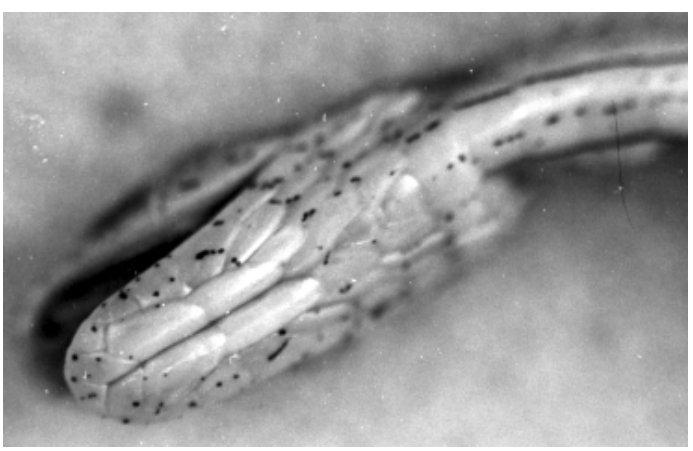

Figure 4 - Typical chin pattern of Thamnodynastes pallidus (MLSB 726). Photo by Mickey Bailey.

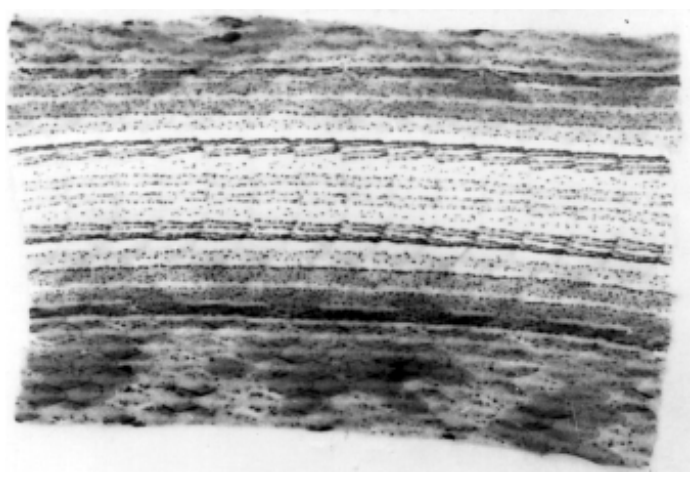

Figure 5 - Ventral pattern of Thamnodynastes pallidus (IB 18533). Photo by Mickey Bailey.

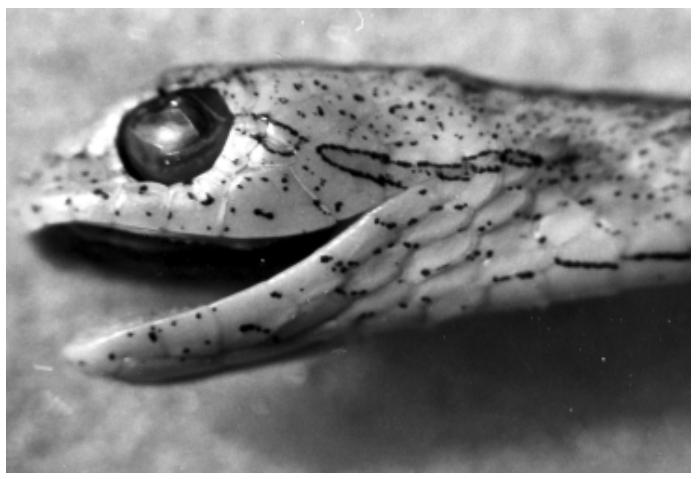

Figure 6 - Hollow ocular strip on Thamnodynastes pallidus (MLSB 726). Photo by Mickey Bailey. specimen in a Heliconia swamp by night, at chest height on a leaf in a dense chorus of frogs that included Scinax cruentomma, Hyla rhodopepla, and Hyla triangulum.”

Broods in T. pallidus are small, usually 5-7, but one female has two and another three or four (10 records). Our data indicate no correlation of brood size with size of female. The largest (465mm SVL) and smallest (340mm SVL) both had six and the one count of seven is from next to the smallest gravid female (350mm SVL). The two small clutches are from middle-size females.

Six near-term embryos from AMNH 2665 measured 108mm \& 110mm SVL for two females and $115-120 \mathrm{~mm}$ for four males. No collection date is given. A juvenile born in captivity May 15, 1976, in Meerzorg, Suriname, died June $1^{\text {st }}$ at $136 \mathrm{~mm}$ SVL. The juveniles (with umbilical scars), also from Meerzorg, bear the date December 6, 1976, and measure $176 \mathrm{~mm}$ and 185mm SVL. Cunha and Nascimento (1978) stated (in translation), "Females with eggs were captured between February and June, and with embryos between June and October, and with developed young between October and February." They further recorded near term embryos of 163mm and 172mm SVL. Probably in equatorial rain forest, which appears the preferred habitat, where dry seasons are neither long nor severe, the reproductive cycle of $T$. pallidus is equally ill-defined.

Identification Corrections - Jan and Sordelli (1872, Livr. 39, Pl. 2, Figure 2) figured a $T$. punctatissimus that is a T. pallidus. Boulenger (1896: 117, a-b, BMNH 78.12.13.10 and 69.5.21.28, respectively) used the same synonym. One record of a specimen from Leticia, Colombia (Silva and Sites 1995: 897), was based on a specimen of this genus collected by NJS that represents a new species that will be described in a forthcoming number in this series.

Thamnodynastes sertanejo sp. nov.

(Figures 8 and 9)

Etymology - Thamnodynastes sertanejo is an inhabitant of the Brazilian sertão, the remote 


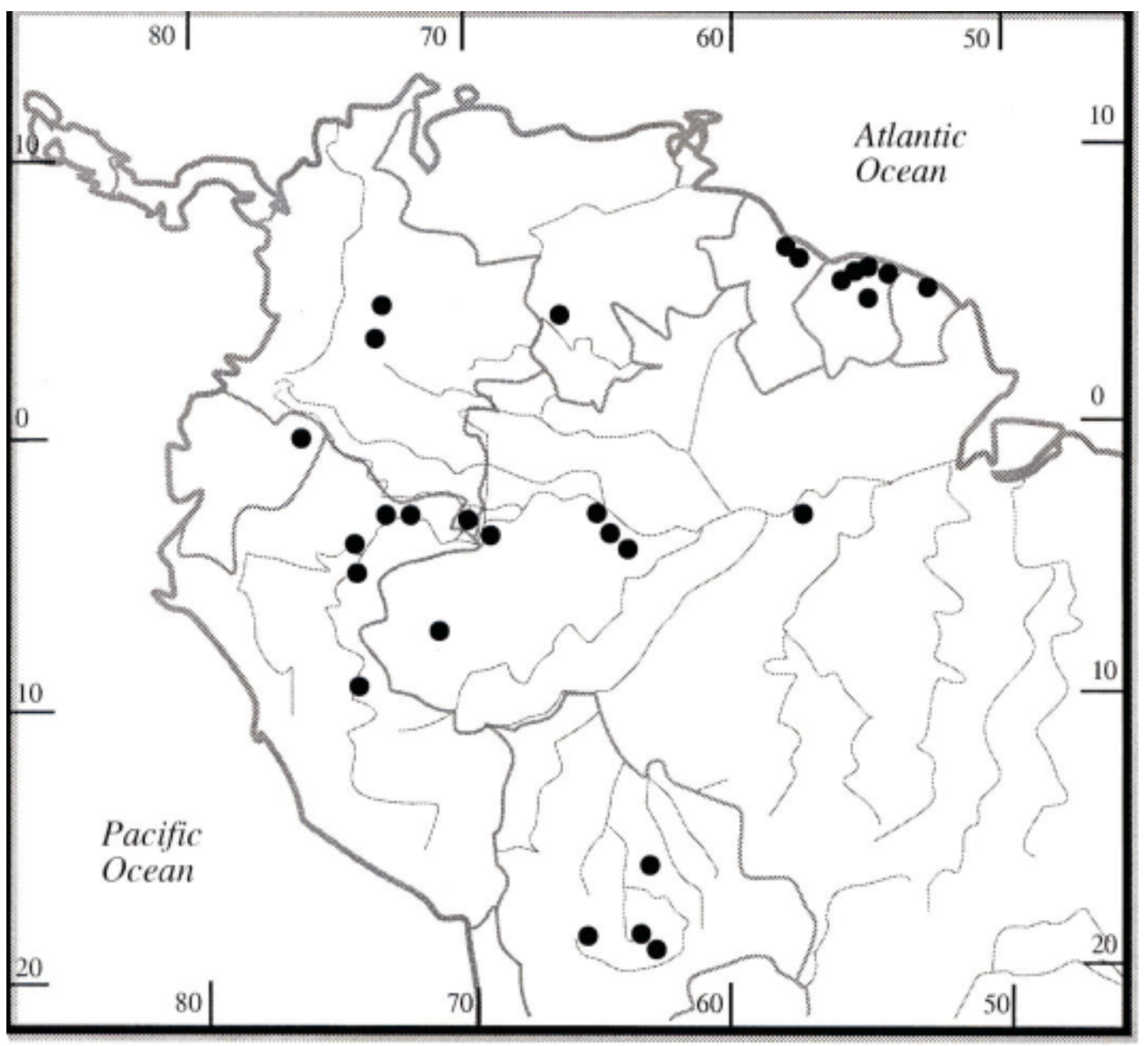

Figure 7 - Distribution of Thamnodynastes pallidus.

hinterlands which provided the title for the Brazilian classic “Os Sertões" by Euclides da Cunha, the setting for which is just that portion of the Caatinga from which this species is known.

Diagnosis - Most closely resembling a new species (to be described in this series) from Amazonian Peru, with which it shares anterior dorsal cross bars and prominent dark ventral blotches, in addition to the pallidus group characters. It differs from other pallidus group species in having two preoculars, about 20 more ventrals, and details of color pattern.

Description of Holotype - An adult female, IBSP 26401, from Caraíba (Mina Caraíba in the original record), at the head of the Rio Curaçá, Bahia, Brazil (Figure 8).

Body 437 mm TL, tail $107 \mathrm{~mm}$; tail/TL 24.5\%; usual colubrid complement of head scales present; supralabials 8-8, IV\&V entering orbit; infralabials 9-9, 5-5 infralabials contacting both genials on each 
side; loreals single; preoculars 2-2; postoculars 2-2; temporals $2+3 / 2+3$; ventrals 157 ; cloacal scale divided; subcaudals 91 and in two rows, terminal spine missing; dorsal scales smooth and without apical pits; scales oblique anteriorly; abbreviated dorsal scale row formula 17-17-11, with the following summation for complete formulae:

$$
17(10) \frac{3+4(101)}{3+4(101)} 15 \frac{6+7(107)}{6+7(107)} 13 \frac{2+3(125)}{2+3(125)} 11(157)
$$

Opisthoglyphous diacranterian maxillary teeth $16+2$.

Eye large, its diameter twice the distance from lip and projected forward reaches edge of rostral; head length twice its width, contained 22.5 times in SVL (330mm).

Head darkish without distinctive markings; darker bands on either side from postoculars at rear center of eye past the angle of the jaw onto the lateral neck; a pair of dark bands diverge from the crown onto the nape; dorsum with ca. 32 faint spots, darker on lighter gray, on either side or joining on the mid-line as saddles
(Figure 9); these separated by lighter areas, each of which contains a central dark spot; chin and throat light with a few intense dark round spots and some of less contrast (Figure 10), but no paragenial stripes; dark ventral markings very irregular (Figure 11), tending toward short, hollow steaks anteriorly, fusing posteriorly to form mottled dark and light blotches with a longitudinal orientation but not arranged in lines typical of the genus.

Variation - This species is known only from three specimens - the holotype and two specimens reported by Vanzolini et al. (1980) (both examined by RAT): MZUSP 7180 (see their Figure 12) and 7181 from the vicinity of Exu, Pernambuco (about $250 \mathrm{~km}$ due north of Caraíba). Both (counts given for MZUSP 7180 and 7181, respectively) males; TL 929 and 640 $\mathrm{mm}$; tail 260 and $167 \mathrm{~mm}$; tail/TL 28.0\% and 26.1\%; ventrals 164 and 161; subcaudals 89 and 93; supralabials entering orbit III-V; one has 10 infralabials, six in contact with chin shields; loreals absent in one, its place shared equally by the nasal and lower preocular; dorsal scale row formulae summary (ventral counts are for MZUSP 7180 followed by 7181):

$$
17(10) \frac{[2] 2+3(103 \& 97)}{\begin{array}{l}
{[1] 2+3(103 \& 97)} \\
{[1] 3+4}
\end{array}} 15 \frac{[2] 6+7(105 \& 99)}{[2] 6+7(105 \& 98)} 13 \frac{[2] 2+3(138 \& 118)}{[2] 2+3(133 \& 119)} 11(164 \& 161)
$$

Prediastemal maxillary teeth 16 , followed by 2 enlarged grooved fangs.

None of these variations from the holotype are considered significant for a member of this group. The coloration is consistent with the holotype. We have not thoroughly examined the hemipenis, but it has a mediumstout hemipenis.

Distribution - See Figure 12. The known localities are in the Caatinga ecosystem, and are apparently restricted to the Rio São Francisco Basin.

Natural History and Ecology - One of the specimens reported above was taken from a termite nest about two meters up on the trunk of a tree (at night?). We suggest it was foraging for tree frogs which are known to seek food and shelter in termite nests.

Behavior - This species spreads its neck when alarmed (Figure 13); this was also reported for Thamnodynastes longicaudus Franco et al. (2003) in its original description.

Identification Correction - As mentioned above, the specimens discussed by Vanzolini et al. (1980, and their Figures 40-42) as T. pallidus are $T$. sertanejo. 


\section{A New Species Not in the Thamnodynastes pallidus Group}

Amaral (1925, 1926) considered Thamnodynastes to be monotypic, and he suggested that a specimen of the genus from Lagoa Gaíba, Mato Grosso do Sul, was an intergrade between T. pallidus (L.) and T. nattereri (Mikan). In fact, that specimen represented an undescribed species that combines characters of the two species (as then understood), but it also has its distinctive suite of characters and a geographical integrity which leaves no doubt that it is a distinct species. Its sympatric and syntopic occurrence in the Pantanal with T. chaquensis first convinced the senior author that the genus needed revision.

\section{Thamnodynastes lanei sp. nov} (Figures 14 and 15)

Etymology - This species is dedicated to the memory of the late entomologist Frederico Lane, who taught the senior author so much of what he knew of Brazil, its people and customs, and who, with his charming wife, Aniuta, graciously opened their home to a sometimes lonely young colleague.

Diagnosis - Dorsal scales keeled, usually in 17 rows; cloacal scale divided; maxillary teeth usually 16-17+2G; ventrals 142-159 in males, 135-153 in females; subcaudals 74-86 in males, 79-85 in females; hemipenis short and slender, ornamented with tiny spines; ventral pattern of four equidistant rows of hollow (double) lines; chin pale with no trace of bars; usually two preoculars per side.

The following characters may be used to separate $T$. lanei from sympatric congeners that have been described (characters are given for the sympatric species, followed parenthetically by characters of T. lanei): T. pallidus has smooth (vs. keeled) dorsal scales, dorsal scale rows 1717-13 or less (vs. 17-17-15), and a single (vs. divided) cloacal scale; T. chaquensis with slightly keeled dorsal scales (vs. keeled), dorsal scale rows 19-19-15 (vs. 17-17-15), and venter heavily suffused with dark pigment (vs. pale); $T$. attenuata has dorsal scale rows 19-19-15 (vs. 17-17-15).

Description of Holotype - An adult male (UMMZ 109081, Figure 14) collected at Salobra, Mato Grosso do Sul, Brazil, January 24, 1941, by Joseph R. Bailey.

Total length $648 \mathrm{~mm}$, tail $169 \mathrm{~mm}$; tail/TL 26.1\%; usual colubrid complement of head scales present; supralabials 8-8, IV\&V entering orbit; infralabials 9-9, 5-5 infralabials contacting both genials on each side; loreals single; preoculars 2-2; postoculars 2-2; temporals $2+3$ / 2+3; ventrals 153; cloacal scale divided; subcaudals 79 and in two rows, terminal spine missing; dorsal scales rather strongly keeled and with two small apical pits; abbreviated dorsal scale row formula 17-17-15, with the following complete formula:

$$
17(10) \frac{3+4(108)}{3+4(108)} 15(153)
$$

Opisthoglyphous diacranterian maxillary teeth $16+2 \mathrm{G}$.

HL $19.4 \mathrm{~mm}$; orbital length $3.8 \mathrm{~mm}$, projecting a little anterior to the front of the nostril; the right hemipenis of the holotype is preserved in everted position; it is about one $\mathrm{cm}$ in length and extends to SC 5 and is slightly bilobed; organ slender to moderately stout, about $2.5 \mathrm{~mm}$ in diameter and ornamented with tiny spinules; these are present very sparingly on the basal portion, but are more dense about half way out; sulcus forks almost at right angles at the base of the two lobes beyond which the tip is virtually smooth; a blunt protuberance is just distal to the sulcal fork; pattern pale with the ground color a light tan; a nuchal stripe extends ca. 12 scales onto neck between two darker para-medial bands which break up into a pair of dorso-lateral rows of irregular spots which are mostly of black skin between the scales, hence of variable conspicuousness according to whether the scales 
are closely imbricate or spread; a similar row of lateral spots present on the skin bordering the fourth scale row; both pairs of spot rows become much reduced at about the anterior third of the body where the more dorsal rows continue as rows of black specks every 2-3 scales and lower rows replaced by a narrow brown lateral stripe continuing onto the tail; rows below the lateral stripes have an indistinct light streak along their centers; head pale brown with scattered dots of darker pigment; nape stripes narrow and continue along the outer edges of the parietals to top of orbit; between these there are some elongate darkish blotches on parietals, frontal, and supraoculars; usual orbit to angle of jaw stripe present and continues faintly through orbit to nostril; scattered pigment dots supralabials and snout; infralabials bear one or two pigment dots each, but mental and genials immaculate; there are no traces of chin bars; four ventral stripes begin gradually on the throat with one dominant dot at the posterior edge of each ventral, with supplementary pigment increasing in intensity and forming four hollow stripes with a very light scattering of stippling between stripes.

Variation - Over its very considerable latitudinal range, only slight variation in total ventral counts is perceptible as shown in Table 1.

Adult size range (based on our largest 25\% of specimens) is $574-648 \mathrm{~mm}$ total length in males, and 567-630 $\mathrm{mm}$ in females; tail/TL $22.4-28.2 \%(\bar{x}=25.8 \pm 1.7, n=17)$ in males, 25.5$30.8 \%(\bar{x}=27.3 \pm 1.6, n=22)$ in females; dorsal scale row formulae 17-17-15(48), scales smooth, without pits, with following complete scale row reduction summary for two specimens:

$$
17(10) \frac{[2] 3+4(93-98)}{[2] 3+4(96-97)} 15(139-157)
$$

Ventrals $142-159(\bar{x}=152.1 \pm 5.1, n=17)$ in males, 135-148 ( $\bar{x}=141.6 \pm 3.4, n=22)$ in females; cloacal scale divided (47), infrequently divided (1); subcaudals 74-90 ( $\bar{x}=81.3 \pm 4.5$, $\mathrm{n}=17)$ in males, 74-85 ( $\overline{\mathrm{x}}=78.5 \pm 3.8, \mathrm{n}=22)$ in females; ventrals +subcaudals 219-242 $(\bar{x}=233.4 \pm 5.8, n=17)$ in males, 213-229 $(\bar{x}=220.1 \pm 4.1, n=22)$ in females; supralabials $8(87)$ or $9(7)$, supralabials entering orbit 3-5(9), $4+5(76)$, or $4-6(1)$; infralabials $8(14)$ or $9(80)$, with $4(6)$ or $5(88)$ touching the genials; loreals 1(94); preoculars $1(4)$ or 2(90); postoculars 2(94); temporals $1+1+2(1), 1+1+3(7), 1+2$ (1), 1+3(8), 2+2(3), 2+3(55); prediastemal maxillary teeth $16(16), 17(14), 18(7)$, or 19(2), followed by two postdiastemal enlarged grooved fangs.

In the Tachymenini, it is usual for males to exceed females in both ventral and subcaudal numbers. In the former character, $T$. lanei, with a mean sexual difference of 10.5 scales, exceed even more slender pallidus group species in which males exceed females by 10.0 to 10.3 scales. In $T$. lanei, however, the subcaudal dimorphism is near the minimum for the genus with male means being 2.8 higher than females. Other species of Thamnodynastes differences range from 2.5 in an undescribed species from northern Venezuela (the only species with a lower difference) to 12.6 in $T$. rutilus Prado. When the tail/TL ratio is calculated, the mean of the females actually exceeds that of the males, the only species in the group in which this is true. The means for the two sexes are $25.8 \%$ for

Table 1 - Geographic and sexual variation in ventral numbers in Thamnodynastes lanei.

\begin{tabular}{lcccccc}
\hline Region & No. & or Range $^{\text {M }}$ & Mean & No. & 申 Range & Mean \\
\hline Argentina to Mato Grosso (BR) & 5 & $142-156$ & 149.2 & 6 & $135-140$ & 137.5 \\
Bolivia to Rondônia (BR) & 4 & $145-159$ & 151.8 & 5 & $139-148$ & 143.6 \\
Pará (BR) & 12 & $149-159$ & 153.5 & 16 & $139-153$ & 143.7 \\
\hline
\end{tabular}



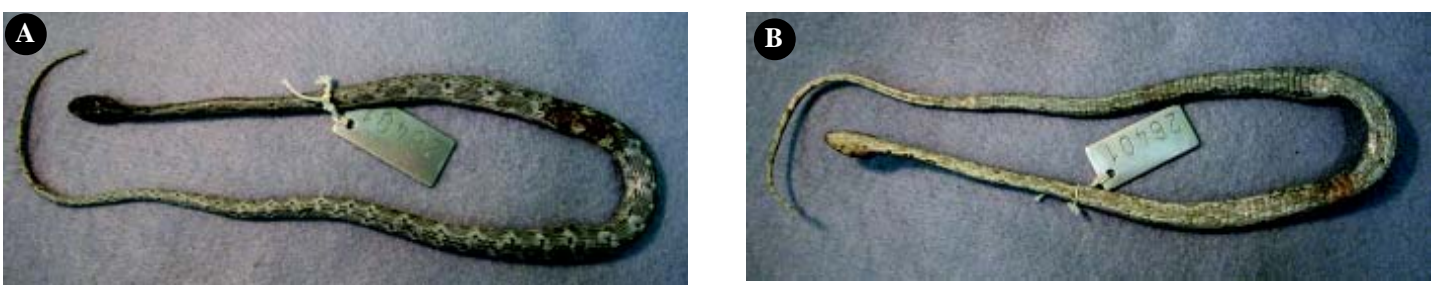

Figure 8 - Thamnodynastes sertanejo holotype (IB 26401). (A) dorsal view, (B) ventral view. Photos by F. L. Franco.

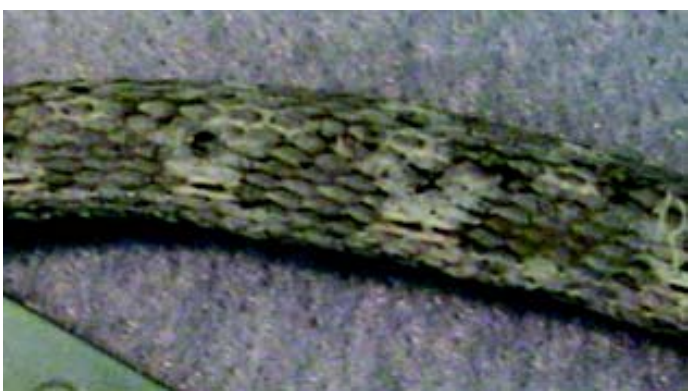

Figure 9 - Dorsal pattern of Thamnodynastes sertanejo (IB 26401). Photo by F. L. Franco.

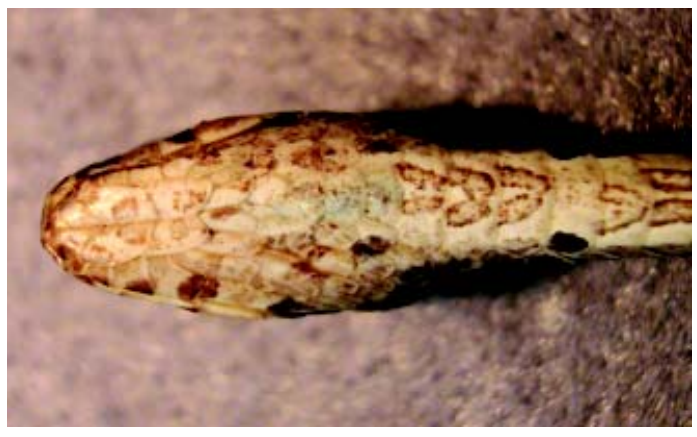

Figure 10 - Chin and neck pattern in Thamnodynastes sertanejo (IB 26401). Photo by F. L. Franco.

17 males and $27.3 \%$ for 22 females.

An in situ hemipenis (IBSP 40517) (cf. holotype description) measures $11.4 \mathrm{~mm}$ long and $2 \mathrm{~mm}$ in diameter, bilobed at $10 \mathrm{~mm}$; sulcal lips very prominent, much higher than the length of the spinules; sulcus forks immediately below the bilobation and there are

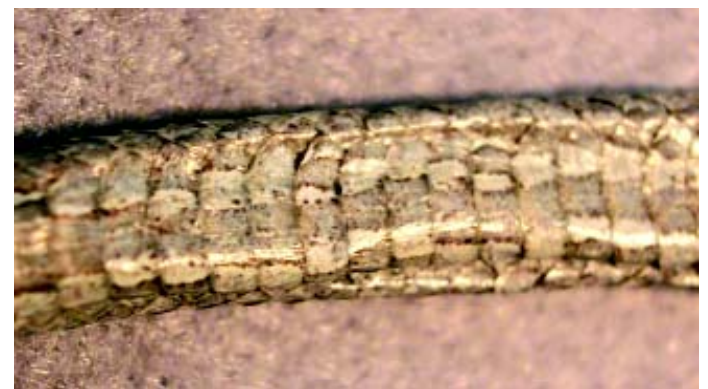

Figure 11 - Ventral pattern of Thamnodynastes sertanejo (IB 26401). Photo by F. L. Franco.

small shallow calyces beyond this point; sulcal lips in dissection are perhaps in part longitudinal folds which diminish upon eversion; a third specimen (AMNH 2973), removed and spread flat, has a hemipenis 5 SC long and measured $1 \mathrm{~cm}$ long and $2 \mathrm{~mm}$ wide; the sulcus forks about $2 \mathrm{~mm}$ from the tip and the hemipenis is bilobed for the last $\mathrm{mm}$; there are about 20 transverse rows of spinules beginning about $2 \mathrm{~mm}$ above the base and continuing to just below the hemipenial fork where they become joined at the bases by membranes and merge into poorly developed calyces, which are more like flat finger-like projections; sulcal lips are prominent and the outer faces bear 3-4 rows of the spinules.

The intensity of the ventral stripes is variable within the populations, but they are never strong or solid. The overall pattern of $T$. lanei is very pale (Figure 15).

Distribution - The known geographical distribution of $T$. lanei is extensive for a 


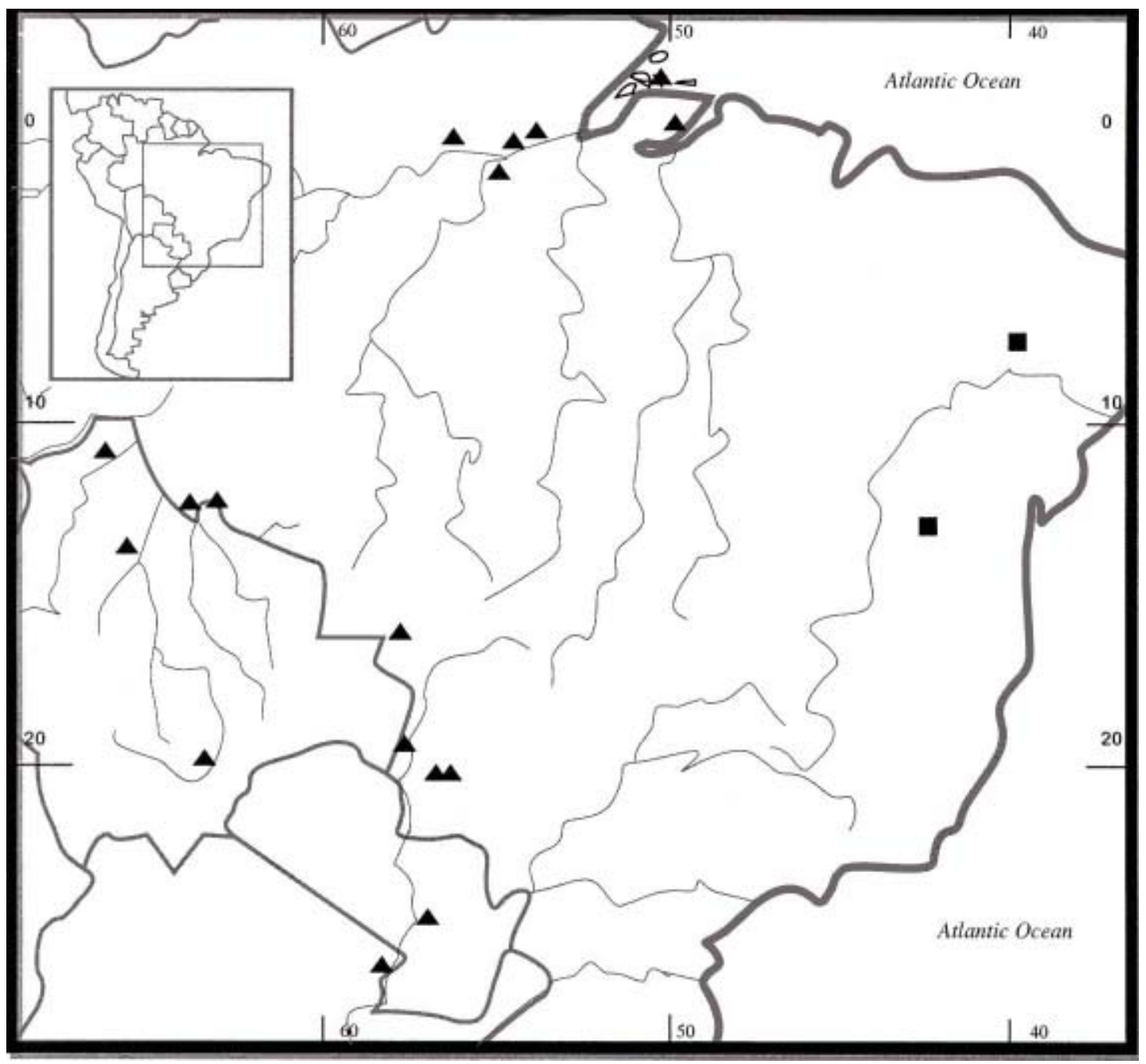

Figure 12 - Distributions of Thamnodynastes lanei (triangles) and T. sertanejo (squares).

species represented by so few specimens (Figure 12). Its known range extends from Formosa in northern Argentina through the Pantanal region of the upper Paraguay basin, thence to the major watersheds of northern and eastern Bolivia. As yet, it is unknown from the Rio Madeira of Brazil (the snake fauna of this area is very poorly known), it shows up again along the lower Amazon from Óbidos to Marajó. Thus, it appears to be a riparian species of large river systems. There are no records any distance from a significant stream along the five thousand kilometers of river arc that provides its range.

A single specimen (ANSP 10131), supposedly from the old Orton Collection, labelled "Río Napo, Perú," is the only record from the upper Amazon region. Two facts give reason to doubt this provenance. Cope (1876, 1877) failed to mention any such specimen in 


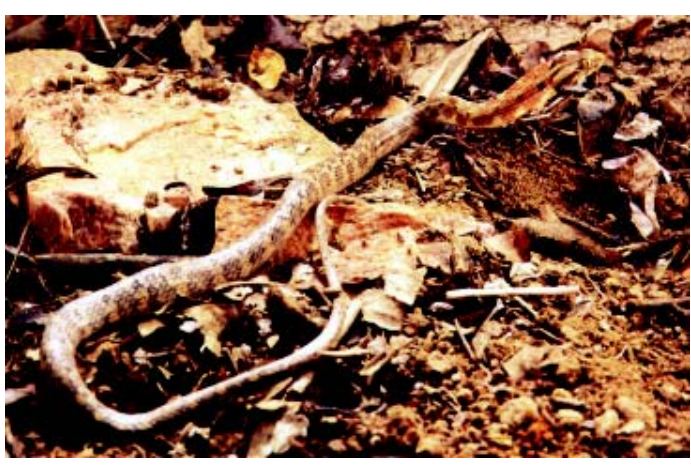

Figure 13 - Expanded neck display of Thamnodynastes sertanejo. Photo by Nelson Jorge da Silva Jr.

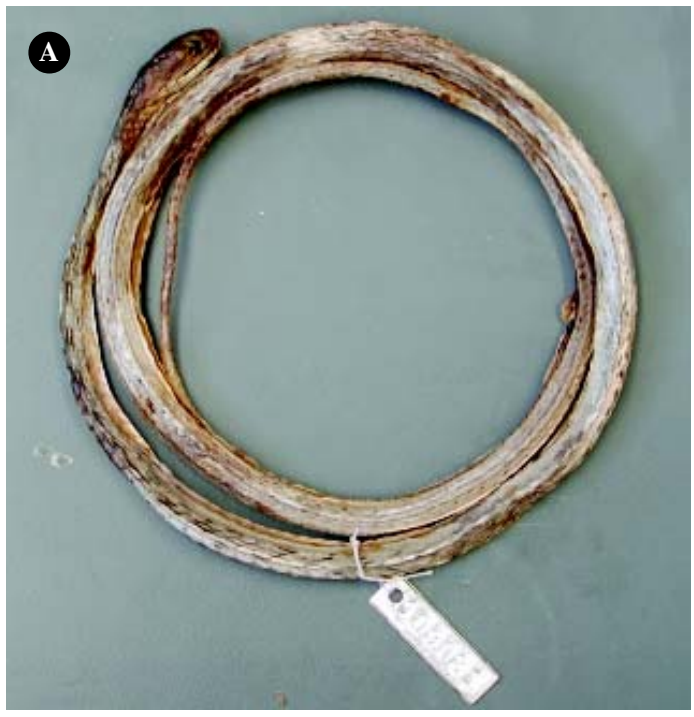

his reports on the Orton material, and it has not turned up in the more recent and very ample collections from the same general area by Bassler, the Olallas, etc., for the AMNH, LSUMZ, and a number of other sources.

Natural History and Ecology - The ecology of the species is poorly known. The senior author took three specimens in the Pantanal in January 1941, before the annual floods which were late that year. Two specimens were taken

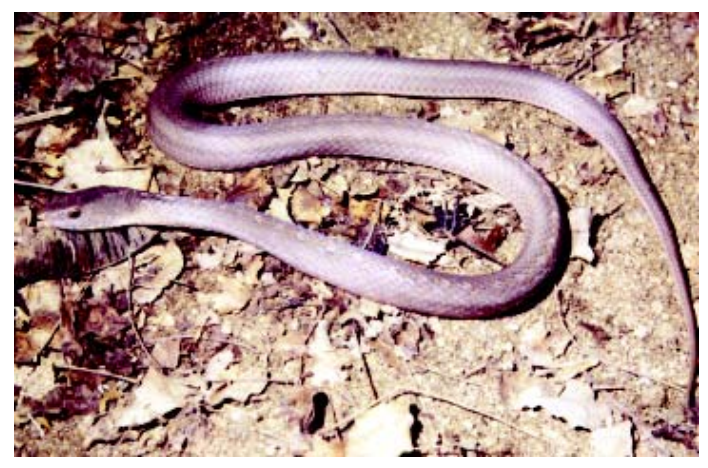

Figure 15 - Thamnodynastes lanei from Xingó, Alagoas, Brazil. Photo by Nelson Jorge da Silva Jr.

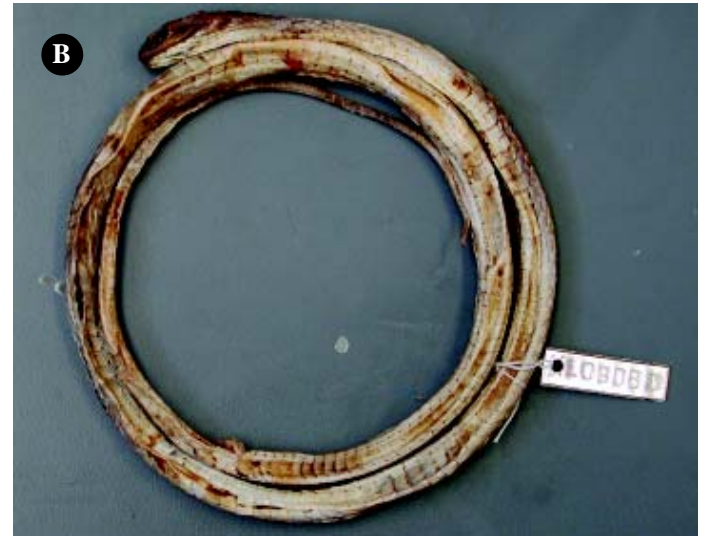

Figure 14 - Thamnodynastes lanei holotype (UMMZ 109081). (A) dorsal view, (B) ventral view. Photos by Greg Schneider.

at Salobra the night of the 24th, one in a low bush and the other climbing in tall grass at the edge of a dry pond in the savannah. The third specimen was found under a board in the afternoon of January 31st, at the edge of the Paraguay River at Porto Esperança. A specimen from Santarém (Griffin 1916) was captured in the water of a swamp between the Rio Tapajós and the Amazon.

The few observations on record plus the 
collection localities and the animals' phenotype all add up to a slender, nocturnal species which climbs in coarse grass and shrubs in seasonally flooded areas or along major water courses. No food records are available, but the above resume would indicate a diet composed largely of small climbing frogs.

Identification Corrections - Boulenger (1896: 116, his specimen Aa) called a specimen (BMNH 56.3.25.18) of T. lanei from Santarém $T$. nattereri. Koslowsky's (1898) specimens "e" and "f", referred to as $T$. nattereri from Miranda, Mato Grosso do Sul, are $T$. lanei. The same is true of CM (Carnegie Museum) 339 from Santarém, Brazil, listed by Griffin (1916). Amaral's (1925) specimen of T. strigilis from Lagoa Gaíba, Mato Grosso do Sul, and his (1926) T. pallidus (based on the same specimen as the preceding report) were both $T$. lanei. We have examined all of the above specimens.

\section{Acknowledgements}

We especially thank Paulo E. Vanzolini, who showed specimens of $T$. sertanejo to Thomas. Klas Allander, Museum of Evolution at Uppsala University, provided photographs of the Linnaean (Thunberg) types of Thamnodynastes strigilis, Greg Schneider provided photos of the UMMZ specimens and Francisco Franco photographed the $T$. sertanejo in the IBSP; the rest were taken by R. A. Thomas. Hobart M. Smith offered sage advice on the neotype designation. Krista Whittington prepared the final versions of the maps. We thank the following curators and collections managers for many courtesies: George Foley, Linda Ford, Charles W. Myers, and Richard G. Zweifel, American Museum of Natural History (AMNH); John E. Cadle, Ned Gilmore, and Edmond V. Malnate, Academy of Natural Sciences in Philadelphia (ANSP); C. J. McCarthy and Andrew F. Stimson, Natural History Museum of London (BMNH); Robert C. Drewes, Alan E.
Leviton, and Jens Vindum, California Academy of Sciences (Stanford University collection) (CAS-SU); the late Avelino Barrio, Colección Herpetologia Instituto Nacional de Microbiológia "Dr. Carlos Malbran," Buenos Aires (CHINM, now at MACN, possibly with the numbers remaining the same, using the acronym CENAI [Centro Nacional de Investigaciónes Iológicas, Buenos Aires]; we use CHINM because we have not been able to personally verify that our specimens are the same as those now using CENAI); the late C. J. McCoy, the late M. Graham Netting, and Ellen J. Censky, Carnegie Museum of Natural History (CM); the Departamento de Ecologia, Universidade de Pernambuco, Recife (DEUP); the late Alphose R. Hoge and S. Alma R. W. L. Romano, Instituto Butantan (IBSP); Joseph T. Collins and William E. Duellman, Museum of Natural History, University of Kansas (KU); the late José María Gallardo and the late Jorge A. Cranwell, Museo Argentino de Ciencias Naturales Bernardino Rivadavia, Buenos Aires (MACN); Abdem R. Lancini, Museo de Ciencias Naturales, Caracas (MCNC); John E. Cadle, Patricia G. Haneline, José Rosado, and the late Ernest E. Williams, Museum of Comparative Zoology, Harvard University (MCZ); the Museo de La Plata, La Plata (MLP); the late Antenor Leitão de Carvalho, Museo Nacional, Rio de Janeiro (MNRJ); Oswaldo R. Cunha, Museu Paraense Emílio Goeldi, Belém (MPEG); Robert W. Henderson and Max A. Nickerson, Milwaukee Public Museum (MPM); Harry W. Greene and David B. Wake, Museum of Vertebrate Zoology, University of California Berkeley (MVZ); Paulo E. Vanzolini, Museu de Zoologia, Universidade de São Paulo (MZUSP); Marinus S. Hoogmoed, Rijksmuseum van Natuurlijke Historie, Leiden (RMNH); Arnold G. Kluge, Ronald Nussbaum, and Greg Schneider, Museum of Zoology, University of Michigan (UMMZ); Hermano Nicéforo María, Museo de Historia Natural La Salle, Bogotá (SCN); James R. Dixon and R. Katheryn Vaughan, Texas Cooperative Wildlife Collection, Texas A\&M 
University, College Station (TCWC); the late Doris M. Cochran, Steve Gotte, W. Ronald Heyer, Frances I. McCullom, the late James A. Peters, Robert P. Reynolds, and George Zug, National Museum of Natural History, Smithsonian Institution (USNM); William W. Lamar, University of Texas at Tyler; and Klas Allander, Mats Eriksson, and Lars Wallin, Uppsala Universitets Zoologiska Museum, Sweden (ZMUU).

\section{References}

Amaral, A. 1925. Ophídios de Matto Grosso (Contribuição II para o conhecimento dos ophídios do Brasil). Commissão de Linhas Telegraphicas Estratégicas de Matto Grosso ao Amazonas, Publicação N. 84, Annexo 5, Historia Natural, Zoologia: 1-29.

Amaral, A. 1926. Notas de ophiologia. 1a. Nota de ophiologia. Sobre a invalidez de um gênero e algumas espécies de ophídios sul-americanos. Revista do $\mathrm{Mu}$ seu Paulista 14: 17-33.

Amaral, A. 1930a. Contribuição ao conhecimento dos ophídios do Brasil. IV. Lista remissiva dos ophídios do Brasil. Memórias do Instituto Butantan 4: 71-125.

Amaral, A. 1930b. Estudos sobre ophídios neotrópicos. XVIII. Lista remissiva dos ophídios da região neotrópica. Memórias do Instituto Butantan 4: 129271.

Andersson, L. G. 1899. Catalogue of Linnean typespecimens of snakes in the Royal Museum in Stockholm. Bihang Till Koeniger Svenska VetenskapsAkademiens Handlingar 24(4): 1-35.

Berthold, A. A. 1840. Über verschiedene neue oder seltene Amphibienarten. Göttingische Gelehrte Anzeigen 2: 889-902.

Boulenger, G. A. 1896. Catalogue of the Snakes in the British Museum (Natural History). Vol. 3. British Museum (Natural History). London.

Cei, J. M. 1993. Reptiles del Noroeste, Nordeste y Este de la Argentina. Herpetofauna de las Selvas Subtropicales, Puna y Pampas. Museo Regionale di Scienze Naturali Torino, Monografia XIV. 949 pp.

Cope, E. D. 1876. Report on the reptiles brought by Professor James Orton from the middle and upper Amazon and western Peru. Journal of the Academy of Natural Sciences of Philadelphia (2)8: 159-188.

Cope, E. D. 1877. Synopsis of the cold blooded vertebrates procured by Prof. James Orton during the exploration of Peru in 1876-77. Proceedings of the American Philosophical Society 17: 33-49.

Cunha, O. R. and F. R. Nascimento. 1978. Ofídios da Amazônia. X. As cobras da região leste do Pará. Publicações Avulsas do Museu Paranese Emílio Goeldi 31: 1-218.

Dowling, H. G. 1951a. A proposed standard system of counting ventrals in snakes. British Journal of Herpetology 1: 97-99.

Dowling, H. G. 1951b. A proposed method of expressing scale reductions in snakes. Copeia 1951: 131-134.

Duméril, A. M. C., G. Bibron and A. Duméril. 1854. Erpetologie Générale. Vol. 7. Pts. I-II. Paris. 1536 pp.

Franco, F. L. and T. G. Ferreira. 2002. Descrição de uma nova espécie de Thamnodynastes Wagler, 1830 (Serpentes, Colubridae) do nordeste brasileiro, com comentários sobre o gênero. Phyllomedusa 1: 57-74.

Franco, F. L., T. G. Ferreira, O. A. V. Marques, and I. Sazima. 2003. A new species of hood-displaying Thamnodynastes (Serpentes: Colubridae) from the Atlantic forest in southeast Brazil. Zootaxa 334: 1-7.

Gmelin, J. F. 1789. Systema Naturae per Regna tria Naturae, Secundum Classes, Ordines, Genera, Species; cum Charateribus Differentiis, Synonymis, Locis. Tome I, Pars III, pp. 1033-1056. George Emanuel Beer. Lipsiae.

Griffin, L. E. 1916. A catalog of the ophidia from South America at present (June, 1916) contained in the Carnegie Museum, with descriptions of some new species. Memoirs of the Carnegie Museum Pittsburgh 7: 163-277.

Hoogmoed, M. S. and U. Gruber. 1983. Spix and Wagler type specimens of reptiles and amphibians in the $\mathrm{Na}$ tural History Musea in Munich (Germany) and Leiden (The Netherlands). Spixiana Supplement 9: 319-415.

Jan, G. 1863. Elenco sistematico degli ofidi descritti e disegnati per l'iconografia générale. A. Lombardi. Milano. 143 pp.

Jan, G. and F. Sordelli. 1872. Iconographie générale des ophidiens. Vol. 3, Livr. 39. Milan: by the authors; London: Baillière, Tindall, \& Cox; Paris: J. B. Baillière \& Sons; Madrid: C. Bailly-Baillière. p. 3.

Koslowsky, J. 1898. Ofidios de Mato-Grosso (Brasil). Revistas Museum La Plata 8: 25-32.

Linnaeus, C. 1758. Systema Naturae per regna tria naturae, secundum classes, ordines, genera, species, cum characteribus, differentiis, synonymis, locis. Tomus I. Editio Decima, reformata. Laurentii Salvii, Holmiae. 824 pp.

Linnaeus, C. 1766. Systema Naturae per regna tria naturae, secundum classes, ordines, genera, species, cum characteribus, differentiis, synonymis, locis. 
Tomus I. Editio Duodecima, reformata. Laurentii Salvii, Holmiae.

Lönnberg, E. 1896. Linnean type-specimens of birds, reptiles, batrachians, and fishes in the Zoological Museum of the R. University in Upsala. Bihang Till Koeniger Svenska Vetenskaps-Akademiens Handlingar 22(4): 1-45.

Schlegel, H. 1837. Essai sur la Physionomie des Serpents. Vol. I: xxviii + 251 pp. Vol. 2. Leiden. M. H. Schnekat. 606 pp.

Silva, Jr., N. J. and J. W. Sites Jr. 1995. Patterns of diversity of Neotropical squamate reptile species, with emphasis on the Brazilian Amazon and the conservation potential of indigenous reserves. Conservation Biology 9: 873-901.

Thomas, R. A. 1976. Comments on the use of dorsal scale row formulae in snakes. Copeia 1976: 839-841.

Thunberg, C. P. 1787. Museum Naturalium Academiae Upsaliensis. F. W. Radloff, Upsalla.
Vanzolini, P. E. 1977. An Annotated Bibliography of the Land and Fresh-water Reptiles of South America (1758-1975). Vol. I (1758-1900). São Paulo. Museu de Zoologia, Universidade de São Paulo. 186 pp.

Vanzolini, P. E., A. M. Ramos-Costa and L. J. Vitt. 1980. Répteis das Caatingas. Rio de Janeiro. Academia Brasileira de Ciências. 161 pp.

Wagler, J. 1824. Serpentum brasiliensium species novae ou Histoire naturelle des espèces nouvelles de serpens, recueillies et observées pendant le voyage dans l'intérieur du Brésil dans les années 1817, 1818, 1819, 1820, exécute par ordre de Sa Majesté le Roi de Bavière, publiée par Jean de Spix, . . ., écrite d'après les notes du voyageur par Jean Wagler. Franc. Seraph. Hubschmann. Monachii. viii + 75 pp.

Wagler, J. 1830. Natürliches System der Amphibien mit vorangehender Classification der Säugethiere und Vögel. Ein Beitrag zur vergleichenden Zoologie. J. G. Cotta’schen, München, Stuttgart, and Tubingen. 354 pp.

Appendix I - Specimens Examined

Thamnodynastes lanei - ARGENTINA. Formosa: Formosa (CHINM 1918). BOLIVIA. Beni: No locality (AMNH 2973); Lake Rogaagua (AMNH 22475); Santa Rosa, Río Mamoré (three Santa Rosa's are on the Río Mamoré: $65^{\circ} 20^{\prime} \mathrm{W} \times 13^{\circ} \mathrm{S}, 64^{\circ} 50^{\prime} \mathrm{W} \times 15^{\circ} 18^{\prime} \mathrm{S}$, $64^{\circ} 42^{\prime} \mathrm{W} \times 15^{\circ} 42^{\prime} \mathrm{S}$ ) (AMNH 101843); Riberalta, Río Beni (UMMZ 63258). Santa Cruz: No locality (MACN 9912); Buenavista, Sara (CM 2919). BRAZIL. Mato Grosso do Sul: No locality (MLP 271a, 277a); Agachi (IBSP 42788); Lagoa Garba (MNRJ Rondon no. 72); Porto Esperança (UMMZ 109082); Solobra (Fazenda Salobra) (UMMZ 109081); Mato Grosso: São Luis de Cáceres (MNRJ 660-661). Pará: No locality (MCZ 4769); Fazenda Nazaré (MPEG 19-10-1901); Marajó, Santo André (AMNH 57327); Monte Alegre (IBSP 40501, 40503, 40505, 40507, 40509, 40511, 40513, 40517, 40519, 40834, 40836, 40840, 40844, 40849, 42497); Monte Alegre, Lagoa Grande (IBSP 42501, 42503); Óbidos (KU 130260-61); Paituna (MNRJ 662); Santarém (BMNH 56.3.25.18); Santarém, between Rio Tapajos and
Amazônas (CM 339); Taparinha (MCZ 2935; MZUSP 5158-59); Lago Ururia, near Oriximiná (MZUSP 4815); Lago Paru, Oriximiná (MZUSP 4816); Ilha Redonda, Gurupa (MZUSP 5375). PARAGUAY. San Pedro: Río Tapiriquay, Alto Paraguay (ca. $24^{\circ} 26^{\prime}$ 'S x 56 $46^{\circ}$ 'W) (BMNH 1962.86). PERU. Loreto: Río Napo (Orton collection; doubtful locality) (ANSP 10131).

Thamnodynastes pallidus - NO DATA. ZMUU 154, 242. BOLIVIA. Cochabamba: No locality (AMNH 6779). Santa Cruz: Buenavista, 450m (BMNH 1927.8.1.207; UMMZ 60792, 63261-62); Santa Cruz de la Sierra (MACN 8817); Provincia de Sara, Río Sirutu, $400 \mathrm{~m}$ (UMMZ 63255). BRAZIL. No locality: ANSP 10132. Acre: Tarauacá (IBSP 18533). Amazonas: Município de Borba (MNRJ 2625); Beruri (MZUSP 5771); Mucuripe, Rio Purus (MZUSP 5760); Rio Manjuru, $57^{\circ} \mathrm{W}$ x $4^{\circ} \mathrm{S}$ (AMNH 101960); São João, Solimões (AMNH 25159); $1 \mathrm{mi} \mathrm{S}$ Leticia, Colombia (MPM 10456). COLOMBIA. Amazonas: Leticia, 100m (KU 124940, MCZ 48989-91); probably Leticia 
(KU 74133). Boyaca: Guaicaramo (SCN 730, AMNH 46472); Meta: Villvicencio (SCN 726). ECUADOR. Río Napo, Limón Cocha (USNM 61207). FRENCH GUIANA. $11.5 \mathrm{~km} \mathrm{E}$ Sinnmary, km marker 91 (TCWC 65403). GUYANA. Demerara, Vryheids Lust, 648’ N x 580'' (BMNH 78.12.13.10); Georgetown, Demerara River (UMMZ 80500); Georgetown (AMNH 2665, 36134; UMMZ 80419); Georgetown, Botanical Gardens (UMMZ 43964). PERU. No locality: "Peruvian Amazons” (BMNH 69.5.21.28). Loreto: Iquitos? (AMNH 55870); Orellana (AMNH 54578, 54585-87, 54891, 54598, 54612, 54615, 54624); Orellano? (AMNH 54639); Requena (AMNH 52648); Requena, Monte Carmelo (AMNH 56056); Pebas (CAS-SU 12499-500); Pebas, Río Ampiyacu (CAS-SU 8723); Explorama Lodge, jct. Río Yanamono and Río Amazonas (KU 220385-386). SURINAME. No locality: RMNH 20983. Commewijne:
Wederezorg (RMNH 5351). Marowijne: Marowijne River, Galibi Station, Old Galibi Lighthouse (MVZ 172401). Nickerie: southeast of Nieuw Nickerie (RMNH 20963-64). Paramaribo: Paramaribo (RMNH 13594, 7696; AMNH 8665); Paramaribo, Cultuurtuin (RMNH 20978-982); Paramaribo, Zorg en Hoop (RMNH 13595). Saramacca: Visgat Monez, Lareco road (RMNH 20974); Coppename River (AMNH 73841). Suriname: 5 km E Meerzorg (RMNH 20958-959); Meerzorg (RMNH 20962); Mattonshoop 23 (RMNH 20975); extension of Gemenelands road, Uitvlugt, Paramaribo (RMNH 20976); Powakka (CM 52405). VENEZUELA. Amazonas: Río Hacha (MCNC 631).

Thamnodynastes sertanejo - BRAZIL. Bahia: Caraíba (IBSP 26401). Pernambuco: Exu (MZUSP 7180, 7181). 